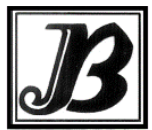

J. Bio-Sci. 28: 13-20, 2020

ISSN 1023-8654

http://www.banglajol.info/index.php/JBS/index

DOI: https://doi.org/10.3329/jbs.v28i0.44706

\title{
GENETIC VARIABILITY, HERITABILITY AND GENETIC ADVANCE OF SOME YIELD CONTRIBUTING CHARACTERS IN LABLAB BEAN (LABLAB PURPUREUS L. SWEET)
}

\author{
N Afsan and AK Roy* \\ Department of Genetic Engineering and Biotechnology, University of Rajshahi, Bangladesh
}

\begin{abstract}
Eleven genotypes of lablab bean were put into trial in four consecutive years to evaluate genetic variability among characters. Genotypic and phenotypic coefficient of variability, heritability and genetic advance as percent of mean were estimated for four yield contributing characters i.e. number of flowers per plant, number of pods per plant, average number of seed per pod and average pod weight (gm). The range of variation was highly pronounced in all the four characters. Without grouping the presence of wide range of variation in these characters indicate that they are quantitative in nature and are under polygenic in control. Mean with standard error showed differences between the varieties and co-efficient of variability in percentage (CV\%) indicates certain degree of variability for the characters studied which are prerequisite in breeding research. Genotypes were found to be significantly different for all characters in analysis of variance. Low differences between PVC and GVC shows that these traits are less influenced by environment and the effect of heritable components were high. High heritability coupled with high genetic advance as percent of mean was recorded by number of flowers per plant, number of pods per plant and average pod weight $(\mathrm{g})$ indicates additive action of genes controlling them.
\end{abstract}

Key words: Genetic advance, Heritability, Lablab bean, Variability, GCV and PCV

\section{Introduction}

Leguminous crop lablab bean [Lablab purpureus (L.) Sweet] (Syn. Dolichos lablab) is one of the important nutritious and popular winter vegetables in Bangladesh (NRC 2006) and is grown extensively all over the country. In our country it is commonly known as 'Shim'. Lablab purpureus (L.) $2 n=2 x=22$ was previously classified as Dolichos lablab, which is known to different parts of the world by different names. Various morphotypes of Lablab bean are grown by the farmers in Bangladesh (Islam et al. 2002). Lablab bean has fleshy and soft texture green pods, which is good source of proteins, fibers and minerals like magnesium, calcium, phosphorus, iron, sulfur and sodium (Deka and Sarker 1990). The dry seeds are also edible which are used for various vegetable preparations. It has a potential future in the third world countries like Bangladesh to minimize the malnutrition problem of our poor people. The foliage of the crop provides hay, silage and green manure. Lablab bean has a well-developed taproot with many laterals and well-developed adventitious root arising from the basis of sprout containing nitrogenous nodules. It can be used advantageously as a cover crop. This cover is able to conserve soil, improve organic matter content and compete with weeds (Humphreys 1995). Lablab bean is drought tolerant crop and an excellent crop to grown in dry lands with limited rainfall which cannot stand water logging condition. Most of the economically important characters of lablab bean are quantitative in nature and show continuous variation.

*Author for correspondence: akoygeb@ru.ac.bd/apu_gen@yahoo.com 
Several statistical methods have been developed for the estimate of inheritance of quantitative character and it is necessary for the planning of effective breeding program in any corp. Extensive research efforts is therefore, necessary for the improvement of lablab bean in our country. A great range of variation exists for the plant and pod characters among the accessions grown all over the country. The success of any breeding programme in general and improvement of specific trait through selection in particular, totally depends upon the genetic variability present in the available germplasm of a particular crop. As yield is a complex character which is influenced by environment, the progress of breeding is conditioned by the magnitude, nature and inter-relationship of genotypic and phenotypic variation. It is very difficult to find whether observed variability is heritable or due to environment alone. For improvement in yield, it is necessary to have the knowledge of genetic variability present in the population, heritability of various characters and probable genetic advance to be expected from selection of superior lines. Information on the nature and magnitude of variability present in the genetic material prior to start any selection breeding programme. Therefore, the present investigation was undertaken with the objective to estimate genetic variability, heritability and genetic advance of various yields and yield contributing characters in four different environments in 11 lablab bean genotypes.

\section{Materials and Methods}

Materials used in this study comprised eleven lablab beans [Lablab purpureus (L.) Sweet] varieties which collected from different places of Bangladesh and preserved in Department of Genetic Engineering and Biotechnology, Rajshahi University, Rajshahi to continue the experiment. These were evaluated during every winter season (August-April) in four years respectively. The experiment area was sandy, loamy and free from water logging where sunlight was available all day long. A spacing of $90 \mathrm{~cm} \times 75 \mathrm{~cm}$ was maintained within pit. The materials were sown to the field in randomized complete block design (RCBD) in six replications. Eleven plants were grown in each replication. The data collected on individual plant basis. Data were recorded on number of flowers per plant (NFP), pods per plant (NPP), average number of seed per pod (ANSP) and average pod weight (APW).

Analysis of variance was done using mixed model, where genotype is fixed and year effect is random. Coefficient of variability at different levels was calculated by following Johanson, et al (1955) and Burton and Devane (1953). Heritability in broad sense was calculated through dividing the genotypic variance by the phenotypic variance and then multiplying it by 100 as suggested by Warner (1952). Genetic advance was calculated by the formula given by Lush (1949).

\section{Results and Discussion}

\section{Variability, heritability and genetic advance analysis}

In the present investigation four quantitative characters of lablab bean in four different environments have been studied. The ranges and mean with standard error and co-efficient of variability (CV\%) in different environments in each of the varieties for four quantitative characters showed a wide range of variation indicating that the characters are quantitative in nature and are under polygenic control (Table 1). In these characters means are significant. Significant differences were found regarding environments in most cases. The highest range was recorded in V- 6 for the character number of flower per plant and lower value for the same was recorded in V-6 for average number of seed per pod. The highest value for mean with standard err-or for all the characters were observed in $\mathrm{V}-15$. A wide range variation was found for mean performances 
has also been reported in dolichos bean by Verma et al. (2015). In the present material the range of variation indicated the degree of co-efficient of variability in percentage (CV\%). Moderately the highest $\mathrm{CV} \%$ was found in V-6 for number of flower per plant and the lowest $\mathrm{CV} \%$ was found in V-5 for average number of seed per pod. Characters indicating high $\mathrm{CV} \%$ in percentage may likely be improved through breeding research.

The mean performances of these four characters of 11 genotypes over four environments and environmental mean performances were computed that presents in Table 2. The performances are also graphically presented in Fig. 1-4. The table and figures show that different genotypes performed differently in different environments for different characters. The highest genotypic mean for all four characters were always observed in V-15.

The mean sum of squares due to genotypes was significant for all the characters under study both at 5 and 1 percent probability levels (Table 3). These referred that the included cultivars would be good material in future breeding researches for the development of those characters and yield. Same result was found by Chandrawat et al. (2017) in soybean. The year ( $Y$ ) variations (in respective four years) were found to be highly significant for number of flower per plant and number of pod per plant, and average number of seed per pod and average pod weight (g) were non-significant. The interaction of $V \times Y$ was found to be significant only for number of flower plant. Reports on different types of significant $\mathrm{G} \times \mathrm{E}$ interaction in rape seed and indian mustard were given by Uddin et al. $(1985,1987)$ and Henry and Daulay $(1988)$ respectively.

The components of variation showed a wide range of phenotypic variation in almost all the characters in eleven varieties (Table 4). Phenotypic variation is the joint product of genotypic, genotypexenvironmental and within error variation. Dewangan et al. (2017) also made similar records in dolichos bean as well as Islam et al. (2011) found in hyacinth bean. Johanson (1909) recorded phenotypic variation in beans (Phaseobes vulgaris L.) due to both environment and heritable effect. Higher genotypic, genotypexenvironmental and within error variation were recorded for number of flower per plant. A wide range of variations existing for various quantitative traits has also been reported in dolichos bean by Ali et al. (2005). Larger genotypic variation for any characters is always helpful for effective selection (Khaleque et al. 1991). Genotypic variation was also found to be high for number of pod per plant which causes high phenotypic variation in the present material.

In the present study, phenotypic coefficient of variance in general were higher than genotype for all the traits, but differences were very low, indicating low environment effect on the expression of all the traits and is suggestive of the heritable nature of the traits. Phenotypic, genotypic and within error co-efficient of variability were found to be the highest for number of pod per plant. In case of genotypexenvironmental co-efficient of variability were found high in number of flower per plant and number of pod per plant. Chaitanya et al. (2014) obtained highest estimates of phenotypic and genotypic co-efficient of variability for marketable pod yield per plant and the number of pods per plant in dolichos bean. High values suggest good scope for improvement of these characters through selection (Saha et al. 1981).

High broad sense heritability $\left(\mathrm{h}^{2} \mathrm{~b}\right)$ with genetic advance in percentage (GA\%) were observed for number of pod per plant, number of pod per plant and average pod weight which indicate that these characters are under additive gene action (Table 4). High heritability $\left(h^{2} b\right)$ found for average number of seed per pod. Upadhyay and Mehta (2010) found high heritability in some traits in dolichos bean. Chandrawat et al. (2017) 
also obtained high heritabilities and high genetic advance in soybean in pods per plant and 100 seed weight. Mazid et al. (1982) studied black gram and found highest genetic advance and genetic advance in percentage of mean for the number of pods per plant and suggested that direct selection for the character would be effective for the improvement of yield. High heritability and moderate genetic advance as percent mean value was observed for the character average number of seed weight indicates the influence of non-additive gene action and considerable influence of environment on the expression of the trait. This trait could be exploited through manifestation of dominance and epistatic component through heterosis.

Table 1. Mean, standard error (SE) and co-efficient of variability in percentage (CV\%) for NFP, NPP, ANSP and APW of 11 genotypes in lablab bean

\begin{tabular}{|c|c|c|c|c|c|c|c|c|c|c|c|c|}
\hline \multirow{2}{*}{ 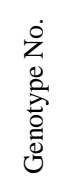 } & \multicolumn{3}{|c|}{ NFP } & \multicolumn{4}{|c|}{ NPP } & \multicolumn{3}{|c|}{ ANSP } & \multicolumn{2}{|c|}{ AWP } \\
\hline & 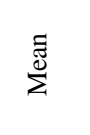 & 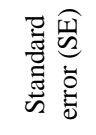 & $\stackrel{3}{0}^{\circ}$ & 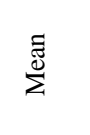 & 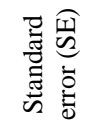 & $\stackrel{8}{u}^{\circ}$ & $\stackrel{\pi}{\Sigma}^{\pi}$ & 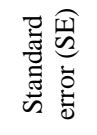 & $\stackrel{8}{0}^{\circ}$ & 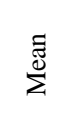 & 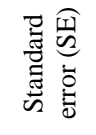 & $\stackrel{\circ}{3}$ \\
\hline V-2 & 471.12 & \pm 16.21 & 16.86 & 306.46 & \pm 10.18 & 16.27 & 3.43 & \pm 0.006 & 0.92 & 7.31 & \pm 0.082 & 5.51 \\
\hline V-3 & 317.75 & \pm 22.73 & 30.05 & 173.96 & \pm 5.15 & 14.49 & 3.84 & \pm 0.012 & 1.48 & 8.59 & \pm 0.185 & 10.56 \\
\hline V-5 & 375.58 & \pm 11.40 & 14.86 & 189.42 & \pm 2.61 & 6.74 & 3.94 & \pm 0.006 & 0.75 & 7.88 & \pm 0.050 & 3.12 \\
\hline V-6 & 394.58 & \pm 31.72 & 39.39 & 215.50 & \pm 4.58 & 10.41 & 3.62 & \pm 0.006 & 0.76 & 6.86 & \pm 0.090 & 6.44 \\
\hline V-7 & 345.25 & \pm 15.32 & 21.74 & 172.17 & \pm 4.68 & 13.31 & 3.49 & \pm 0.011 & 1.61 & 6.28 & \pm 0.033 & 2.54 \\
\hline V-9 & 282.75 & \pm 8.47 & 14.67 & 147.58 & \pm 3.63 & 12.05 & 3.92 & \pm 0.023 & 2.86 & 8.19 & \pm 0.290 & 1.73 \\
\hline V-11 & 301.08 & \pm 11.74 & 19.10 & 142.42 & \pm 4.28 & 14.74 & 3.77 & \pm 0.017 & 2.23 & 7.93 & \pm 0.035 & 2.15 \\
\hline V-12 & 355.96 & \pm 11.17 & 15.37 & 209.79 & \pm 6.83 & 15.96 & 3.29 & \pm 0.019 & 2.84 & 5.92 & \pm 0.022 & 1.84 \\
\hline V-13 & 391.58 & \pm 10.37 & 12.98 & 196.12 & \pm 3.04 & 7.60 & 3.98 & \pm 0.028 & 3.48 & 8.56 & \pm 0.050 & 2.85 \\
\hline V-14 & 426.37 & \pm 15.12 & 17.37 & 258.08 & \pm 4.87 & 9.24 & 3.99 & \pm 0.016 & 1.99 & 8.15 & \pm 0.026 & 1.55 \\
\hline V-15 & 503.04 & \pm 9.68 & 9.43 & 325.75 & \pm 9.12 & 13.72 & 4.02 & \pm 0.024 & 2.96 & 9.28 & \pm 0.038 & 2.02 \\
\hline
\end{tabular}

Table 2. Environmental Mean for NFP, NPP, ANSP and APW of 11 genotypes in lablab bean

\begin{tabular}{ccccc}
\hline \multirow{2}{*}{$\begin{array}{c}\text { Environment } \\
\text { (Year) }\end{array}$} & \multicolumn{4}{c}{ Mean } \\
\cline { 2 - 5 } & NFP & NPP & ANSP & APW \\
\hline 1 & 397.818 & 220.061 & 3.756 & 7.782 \\
2 & 366.091 & 207.742 & 3.761 & 7.702 \\
3 & 374.182 & 209.242 & 3.754 & 7.709 \\
4 & 376.621 & 212.409 & 3.685 & 7.701 \\
\hline
\end{tabular}


Table 3. ANOVA table of $\mathrm{G} \times \mathrm{E}$ interaction of 11 genotypes of lablab bean for four characters

\begin{tabular}{|c|c|c|c|c|c|}
\hline Characters & Item & Df & SS & MS & F. value \\
\hline \multirow[t]{4}{*}{ NFP } & Genotypes (V) & 10 & 1134859.530 & 113485.953 & $181.0640^{\star \star \star}$ \\
\hline & Year (Y) & 3 & 36286.9545 & 12095.6515 & $19.2983^{\star \star \star}$ \\
\hline & $V \times Y$ & 30 & 33659.0452 & 1121.9682 & $1.7901^{\star \star \star}$ \\
\hline & Error & 220 & 137889.9997 & 626.7727 & \\
\hline \multirow[t]{4}{*}{ NPP } & Genotypes (V) & 10 & 877282.4242 & 87728.2424 & 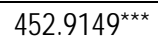 \\
\hline & Year $(\mathrm{Y})$ & 3 & 5962.6364 & 1987.5455 & $10.2611^{\star * \star}$ \\
\hline & $V \times Y$ & 30 & 3768.6970 & 125.6232 & $0.6486^{\mathrm{NS}}$ \\
\hline & Error & 220 & 42613.3333 & 193.6970 & \\
\hline \multirow[t]{4}{*}{ ANSP } & Genotypes (V) & 10 & 15.6633 & 1.5663 & $326.3125^{\star \star \star}$ \\
\hline & Year $(Y)$ & 3 & 0.0055 & 0.0018 & $0.3750^{\mathrm{NS}}$ \\
\hline & $V \times Y$ & 30 & 0.071 & 0.0024 & $0.4931^{\mathrm{NS}}$ \\
\hline & Error & 220 & 1.0556 & 0.0048 & \\
\hline \multirow[t]{4}{*}{ APW } & Genotypes (V) & 10 & 253.5182 & 25.3518 & $531.4843^{\star \star \star}$ \\
\hline & Year $(Y)$ & 3 & 0.1548 & 0.0516 & $1.0818^{\mathrm{NS}}$ \\
\hline & $V \times Y$ & 30 & 1.2318 & 0.0411 & $0.8616^{\mathrm{NS}}$ \\
\hline & Error & 220 & 10.2491 & 0.0477 & \\
\hline
\end{tabular}

Table 4. Phenotypic variance $\left(\sigma^{2} \mathrm{p}\right)$, genotypic variance $\left(\sigma^{2} \mathrm{~g}\right)$, phenotypic variance $(\mathrm{PCV})$, genotypic variance $(G C V)$, interactions $\{(V \times Y) C V\}$ and within error $(E C V)$ co-efficient of variation, heritability $\left(h^{2}{ }_{b}\right)$, genetic advance (GA) and genetic advance as percentage of mean (GA\%) of 4 quantitative characters of 11 genotypes in lablab bean

\begin{tabular}{cccccccccc}
\hline Character & $\sigma^{2}{ }_{p}$ & $\sigma^{2} g$ & PCV & GCV & $(V \times Y) C V$ & ECV & $h^{2}{ }_{b}$ & GA & GA\% \\
\hline NFP & 5391.14 & 4681.84 & 1423.80 & 1236.47 & 21.80 & 165.53 & 86.84 & 122.41 & 32.33 \\
NPP & 3832.46 & 3650.11 & 1804.67 & 1718.80 & -5.34 & 91.21 & 95.24 & 118.54 & 55.82 \\
ANSP & 0.07 & 0.065 & 1.854 & 1.7363 & -0.011 & 0.128 & 93.68 & 0.493 & 13.12 \\
APW & 1.102 & 0.055 & 14.26 & 13.659 & -0.014 & 0.6176 & 95.77 & 2.026 & 26.24 \\
\hline
\end{tabular}




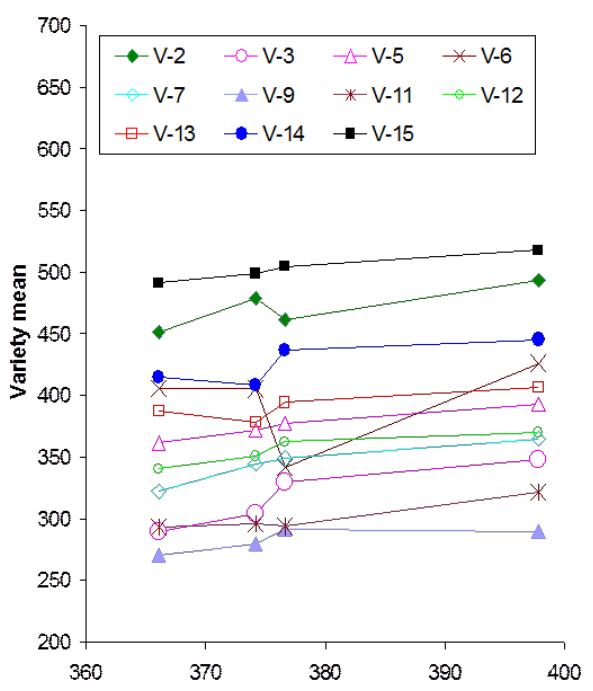

Fig. 1. Performance of genotypes over environments for NFP of 11 genotypes of lablab bean

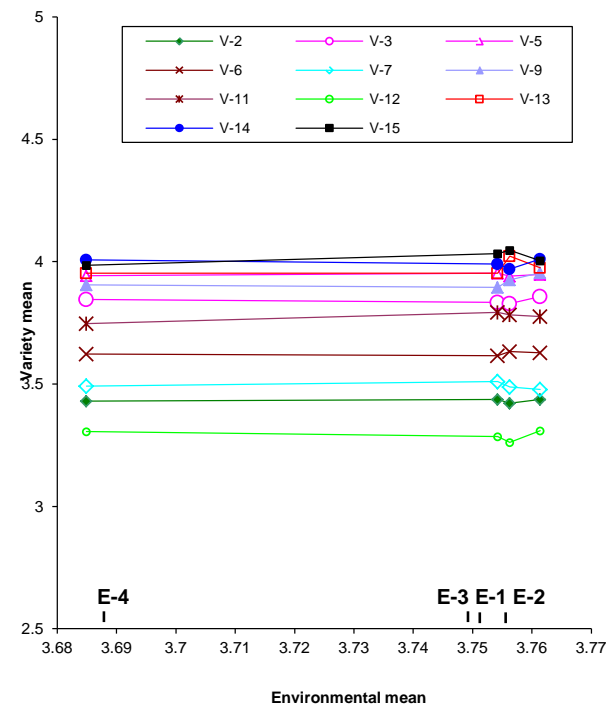

Fig. 3. Performance of genotypes over environments for ANSP of 11 varieties of lablab bean

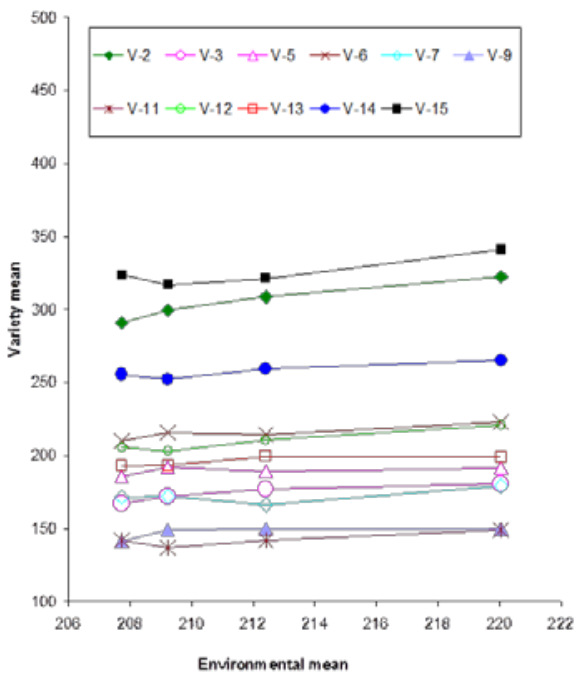

Fig. 2. Performance of genotype over environments for NPP of 11 genotypes of lablab bean

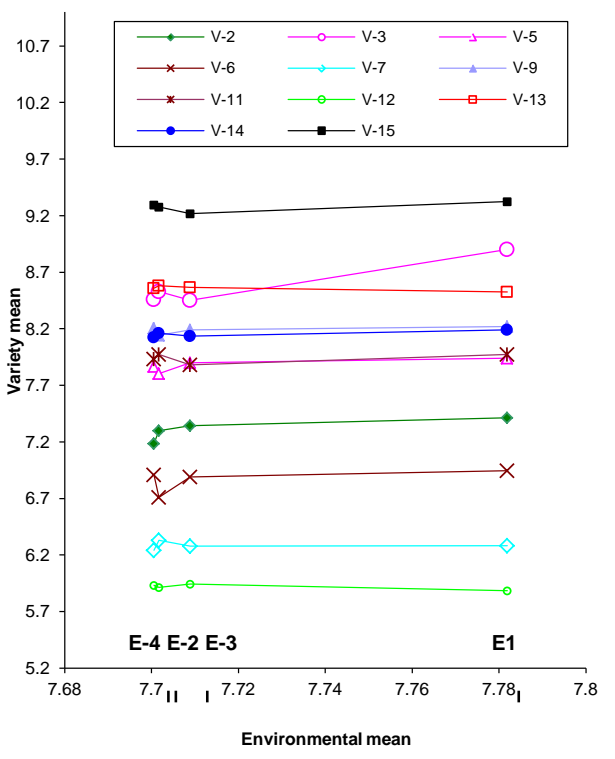

Fig. 4. Performance of genotypes over environments for APW of 11 varieties of lablab bean 


\section{Conclusion}

It can be concluded from these estimates of genetic variability that individual plant selection for characters viz. number of flower per plant, number of pod per plant and average pod weight showing high values of heritability, genetic advance, genetic advance as percent mean values, GCV and PCV concurrently, would directly effective in the offspring of lablab bean. However, the breeder should adopt suitable breeding methodology to utilize both additive and non-additive gene effects simultaneously, as varietal and hybrid development will take place to open new era especially in case of dolichos bean.

\section{References}

Ali F, Sikdar B, Roy AK and Joarder OI (2005). Correlation and genetic variation of twenty different genotypes of lablab bean. Lablab purpureus (L.) sweet. Bangladesh J. Bot., 34(2): 125-128.

Burton GW and Devane EM (1953). Estimating heritability in tall fescue (Festuca arundinacea) from replicated clonal material. Agron. J, 45: 478-481.

Chaitanya V, Reddy RVSK and Kumar PA (2014). Variability, heritability and genetic advance in indigenous dolichos bean (Dolichos lablab L. var Typicus) genotypes. Plant Archives, 14 (1): 503-506.

Chandrawat KS, Baig KS, Hashmi S, Sarang DH, Kumar A and Dumai K (2017). Study on genetic variability, heritability and genetic advance in soybean. Int. J. Pure App. Biosci., 5(1): 57-63.

Deka RK and Sarkar CR (1990). Nutrient composition and antinutritional factors of Dolichos lablab (L.) seeds. Food Chemistry, 38: 239-246.

Dewangan R, Bahadur V, Choyal P, Ramesh, Xaxa S, Sing VP, Sachan S and Kerketta A (2017). Study on genetic variability, heritability and genetic advance in dolichos bean (Lablab purpureus L.) genotypes. Int. J. Curr. Microbiol. App. Sci., 6(8): 3228-3232.

Henry A and Daulay HS (1988). Genotype-environment interaction for seed yield in Indian mustard (Brassica juncea sub sp. juncea). Indian J. Agric. Sci., 58(10): 794-795.

Humphreys LR (1995). Diversity of productivity of tropical legumes. In: Tropical legumes in animal nutrition: D'Mello, JPF and C Devendra (eds.) CAB International. Wallingford. UK, pp. 1-21.

Islam T, Haque MN and Rahman MM (2002). Catalogue on hyacinth bean germplasm. PGRC., BARI, Gazipur, pp. 55.

Islam MS, Rahman MM and Mian MAK (2011). Genetic variability, heritability and correlation study in hyacinth bean. Bang. J. Agric. Res., 36(2): 351-356.

Jonannsen W (1909). Elemenate der exakten Erblichkeitalehre. Jena: Gustav Fisher. First eddition, pp. 515.

Johanson HW, Robinson HF and Comstock RE (1955). Estimates of genetic and environmental variability in soyabean. Agron. J., 47: 314-318.

Khaleque MA, Illias GNM and Quisuddin M (1991). Study of variability and correlation of some chemical characteristics in chili (Capsicum annum L.). Bangladesh J. Bot., 20(1): 37-41.

Lush JL (1949). Plant breeding plans. lowa state Univ. Press Ames.

Majid MA, Khanum S, Shaikh MAQ and Bhuiya AD (1982). Genetic variability and correlation studies in Black gram. Bangladesh J. Agric., 7(3\&4): 98-102.

NRC (2006). Lablab. In: Lost crops of Africa, vol. II: vegetables. NRC, Washington DC, USA, pp. 190-205.

Saha HK, Razzaque CA, Islam MA and Hasif MA (1981). Genetic variability and some biometrical characters in verginia tobacco. Bangladesh J. Plant Breeding and Genetics, 1(1\&2): 54-61. 
Uddin MM, Begum S, Samad A and Salam MA (1985). Genotype-environment interaction of some quantitative characters of masterd and rape seed. Bangladesh J. Sci. Ind. Res., XX(1-4): 77-84.

Uddin MM, Samad MA, Khan MR, Begum S, Hossain K and Khaleda S (1987). Variety sowing date interaction in masterd and rape seed. Bangladesh J. Agric. Res., 12(2): 55-60.

Upadhyay D and Mehta N (2010). Biometrical studies in dolichos bean (Lablab purpureus L.) for Chattisgarh plains. Res. J. Agric. Sci., 1(4): 441-447.

Verma AK, Jyothi KU and Rao AVD (2015). Variability and character association studies in dolichos bean (Lablab purpureus L.) genotypes. Indian J. Agric. Res., 49(1): 46-52.

Warner JN (1952). A method of estimating heritability. Agron. J., 44: 427-430.

(Manuscript received on June 14, 2019 and revised on August 20, 2019) 